Vol 11, Issue 8, 2018

\title{
PHYTOCHEMICAL SCREENING AND ANTI-INFLAMMATORY ACTIVITY OF FRACTIONS FROM SAMBUNG RAMBAT (MICANIA CORDATA) LEAF
}

\author{
ZOLA EFA HARNIS ${ }^{1 *}$, PANAL SITORUS ${ }^{1}$, ROSIDAH ROSIDAH ${ }^{2}$ \\ ${ }^{1}$ Department of Biological Pharmacy, Faculty of Pharmacy, University of Sumatera Utara, Medan, Indonesia. ${ }^{2}$ Department of Pharmacology, \\ Faculty of Pharmacy, University of Sumatera Utara, Medan, Indonesia. Email: zolaefaharnisgh@gmail.com
}

Received: 20 March 2018, Revised and Accepted: 25 April 2018

\section{ABSTRACT}

Objective: The present study is to evaluate the anti-inflammatory activity of various fractions from Sambung Rambat leaf (Micania cordata) using ethyl acetate, hexane, and water solvent as the solvent.

Methods: Investigation of phytochemical compound was using standard phytochemical screening method, while the anti-inflammatory was using the carrageenan-induced paw edema method in animal (rats) model.

Results: The phytochemical screening showed that the fractions of $M$. cordata had a lot of phytochemical compounds such as flavonoids, glycosides, steroids, triterpenoids, tannins, and saponins. Anti-inflammatory assessment showed that the strongest activity of anti-inflammatory produced by ethyl acetate fraction with $200 \mathrm{mg} / \mathrm{kg} \mathrm{BW}$ dose.

Conclusion: This investigation could be concluded that ethyl acetate fraction of $M$. cordata might be a potential for the treatment of inflammatory.

Keywords: Anti-inflammatory, Carrageenan, Micania cordata, Phytochemical, Screening.

(C) 2018 The Authors. Published by Innovare Academic Sciences Pvt Ltd. This is an open access article under the CC BY license (http://creativecommons. org/licenses/by/4. 0/) DOI: http://dx.doi.org/10.22159/ajpcr.2018.v11i8.26083

\section{INTRODUCTION}

Inflammation is defined as the local response of living mammalian tissues to injury due to any agent. It is a body defense reaction to eliminate or limit the spread of injurious agent, followed by removal of the necroses cells and tissues [1]. Inflammation is characterized in acute phase by increased blood flow and vascular permeability along with the accumulation of fluid, leukocytes, and inflammatory mediators such as cytokines [2].

Micania cordata (Compositae) also known as "sambung rambat or heartleaf hempvine" is a plant that grows widely in tropical area, such as Asian, Africa, and South America [3]. In traditional medicine, this plant has been used occasionally for the treatment of ulcers, analgesic, inflammatory, cancer, stressness [4-6] dysentery, itching, cough, headache [7,8], and wounds [9]. In this regard, it makes great sense to evaluate the anti-inflammatory activity of various $M$. cordata leaf fractions in a carrageenan-induced inflammatory using animal (rats) model.

\section{METHODS}

Collection and authentication of plant materials

Fresh sambung rambat (M. cordata) leaf was collected in March 2017 from local area of Punden Rejo, Deli Serdang (North Sumatera, Indonesia) and authenticated by Indonesian Institute of Sciences: Research Center for Biology.

\section{Preparation of extract and fractions}

Extraction was done by a stratified maceration method using ethanolic solvent. $1 \mathrm{~kg}$ of powdered M. cordata leaf was macerated using $7.5 \mathrm{~L}$ ethanol solvent for 5 days, then filtered, do it continuously until the filtrate obtained is clear and colorless. $20 \mathrm{~g}$ concentrated ethanolic extract, then fractioned with ethyl acetate, hexane, and water solvent to get the fractions $[10,11]$.
Preliminary phytochemical screening of extract and fractions Phytochemical screening carried out on M. cordata leaf fractions which are ethyl acetate, hexane, and water solvent includes examing the chemical secondary metabolites of alkaloids, flavonoids, glycosides, tannins, triterpenoids, and steroids [12-15].

\section{Preparation of animals}

Healthy adult male Wistar rats (175-200 g body weight) from animal house of Faculty of Pharmacy, University of Sumatera Utara, were used for the study. Mice were housed in a polycarbonate cage in a room with $12 \mathrm{hrs}$ day-night circle. They were fed on a standard pellet diet and water ad libitum [16]. The study was approved by Animal Research Ethics Committees (AREC) of University of Sumatera Utara (AREC Registration Number: No. 130/KEPH-FMIPA/2017), and the experiments were conducted according to the ethical norms and AREC guidelines.

\section{Inflammation method design}

Carrageenan was prepared as a $1 \% \mathrm{w} / \mathrm{v}$ solution in $0.9 \%$ saline. Healthy adult male Wistar rats were divided into five groups of six rats each. Edema was induced by injecting $0.05 \mathrm{~mL}$ of $1 \%$ carrageenan suspension into the subplantar region of the right hind paw of the rats. Control group rats received $0.5 \%(\mathrm{w} / \mathrm{v}) \mathrm{Na} \mathrm{CMC}$, and the reference group of rats received $2.25 \mathrm{mg} / \mathrm{kg} \mathrm{BW}$ sodium diclofenac, orally. The test groups of rats were treated orally with $200 \mathrm{mg} / \mathrm{kg}$ BW ethanolic extract, ethyl acetate fraction, and hexane fraction consecutively. The paw volume was measured by plethysmometer before carrageenan injection $\left(\mathrm{V}_{0}\right)$ and $30,60,90,120,150$, and 180 min after $\left(V_{t}\right)$. The inflammation was calculated as the increase in volume (mL) of the paw after treatment subtracted of basal volume. Results were expressed as percentage of inhibition of edema, calculated according to the formula $[17,18]$ :

\section{Mean paw inflammation ofcontrol-}

Percentage inhibition $(\%)=\frac{\text { Mean paw inflammation of test }}{\text { Mean paw inflammation of control }} \times 100$ 
Table 1: Phytochemical screening result of various Micania cordata leaf

\begin{tabular}{llll}
\hline No & Screening & Ethyl acetate fraction & Hexane fraction \\
\hline 1 & Alkaloids & Negative & Negative \\
2 & Flavonoids & Positive & Negative \\
3 & Glycosides & Positive & Negative \\
4 & Saponins & Positive & Negative \\
5 & Tannins & Positive & Negative \\
6 & Triterpenoid/Steroids & Negative & Positive \\
\hline
\end{tabular}

Table 2: Effect of various fractions of Micania cordata leaf on the paw edema volume

\begin{tabular}{|c|c|c|c|c|c|c|}
\hline \multirow[t]{2}{*}{ Group } & \multicolumn{6}{|c|}{ Paw edema volume } \\
\hline & $30 \prime$ & $60^{\prime}$ & $90^{\prime}$ & $120^{\prime}$ & $150^{\prime}$ & $180^{\prime}$ \\
\hline Group I (control negative) & $4.09 \pm 0.29^{\#}$ & $4.55 \pm 0.49^{\#}$ & $4.73 \pm 0.59^{\#}$ & $4.72 \pm 0.52^{\#}$ & $4.88 \pm 0.34^{\#}$ & $4.98 \pm 0.43^{\#}$ \\
\hline Group III (ethyl acetate 200 mg/kg) & $3.56 \pm 0.11^{* \#}$ & $3.86 \pm 0.10^{* \#}$ & $3.86 \pm 0.13^{* \#}$ & $3.72 \pm 0.24^{* \#}$ & $3.64 \pm 0.19^{* \#}$ & $3.53 \pm 0.22^{* \#}$ \\
\hline Group IV (hexane fraction $200 \mathrm{mg} / \mathrm{kg}$ ) & $3.84 \pm 0.39 * \#$ & $4.35 \pm 0.42^{* \#}$ & $4.45 \pm 0.40^{* \#}$ & $4.56 \pm 0.42^{* \#}$ & $4.88 \pm 0.34^{* \#}$ & $4.97 \pm 0.36^{* \#}$ \\
\hline Group V (water fraction $200 \mathrm{mg} / \mathrm{kg}$ ) & $3.96 \pm 0.15^{* \#}$ & $4.38 \pm 0.67^{* \#}$ & $4.53 \pm 0.24^{* \#}$ & $4.21 \pm 0.14^{* \#}$ & $4.33 \pm 0.34^{* \#}$ & $4.37 \pm 0.36^{* \#}$ \\
\hline
\end{tabular}

Values are given as mean \pm SEM for five mice in each group. *Differ significantly to control negative; \#Differ significantly to control positive. SEM: Standard error of the mean

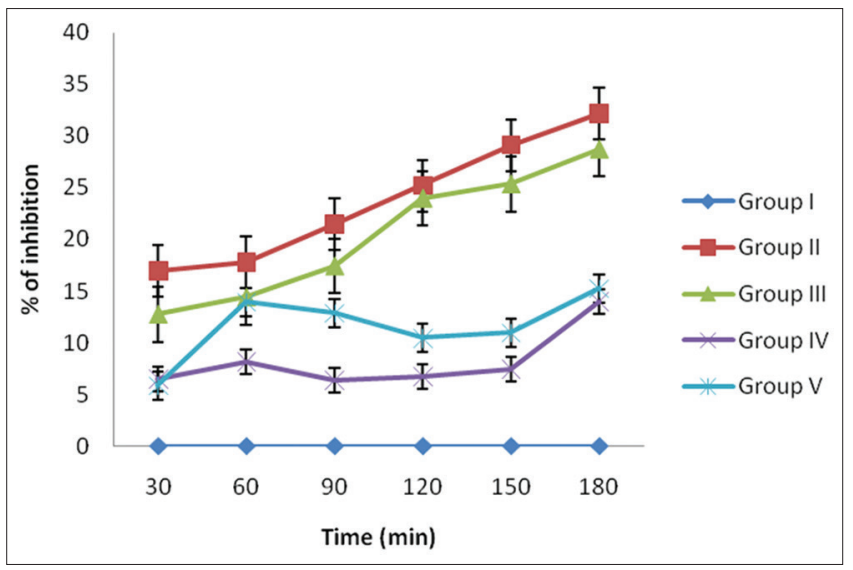

Fig. 1. Effect of various fractions of Micania cordata on the percentage of inhibition

Statistical analysis

All the data were expressed as mean \pm standard deviation. The significant difference of data between different groups was compared by ANOVA followed by Duncan's test.

\section{RESULTS}

\section{Phytochemical screening}

Table 1 summarizes the phytochemical screening results of various extract and fractions of $M$. cordata leaf which showed different chemical compound in different extract and fractions.

Effect of $M$. cordata fractions on carrageenan-induced inflammatory To evaluate the effect of $M$. cordata leaf fractions on the carrageenan induced of inflammatory, the paw volumes and percentage of inhibition of the control, standard, and test groups are shown in Fig. 1 and Table 2. These results showed that the ethyl acetate fraction of $M$. cordata leaf (dose $200 \mathrm{mg} / \mathrm{kg} \mathrm{BW}$ ) has the most potential anti-inflammatory activity.

\section{DISCUSSION}

Inflammation is a response triggered when there is a damage on the living tissues. This defense mechanism is a response to protect against infection and injury. The result of this study indicates that the leaf fractions of $M$. cordata process anti-inflammatory activity against carrageenan induction agent. The ethyl acetate fraction showed significant inhibition of edema rather than hexane and water fraction.
This result strongly indicated that the anti-inflammatory activity come from the ethyl acetate fraction with the non steroidal type. The presences of flavonoids in the ethyl acetate fraction may count for its observed pharmacological activities. Many compounds from this class have been found to exhibit anti-inflammatory effects. Previous studies have shown similar relationships between flavonoids and antiinflammatory effects [1922]. Therefore, it is possible that the antiinflammatory action of $M$. cordata may be related to the inhibition of prostaglandin synthesis. The phytochemical profile of M. cordata may be explored further to identify the active constituents responsible for its anti-inflammatory activity.

\section{CONCLUSION}

It is clearly evident that the ethyl acetate fraction of $M$. cordata leaf possesses significant anti-inflammatory activity in rats. This may be due to the presence of the natural phytochemical constituents. Further studies are needed to determine the exact molecular mechanism involved in the process of anti-inflammatory.

\section{ACKNOWLEDGMENTS}

The authors thank Iksen, B.Pharm., M.Sc. of Sekolah Tinggi Ilmu Kesehatan Senior for his support and guidance for this publication.

\section{AUTHOR'S CONTRIBUTIONS}

All the authors have contributed equally.

\section{CONFLICTS OF INTEREST}

The authors declare that there are no conflicts of interest regarding the publication of this paper.

\section{REFERENCES}

1. Leelaprakash G, Dass SM. In vitro anti-inflmmatory activity of methanol extract of Enicostemma axillare. Int J Drug Dev Res 2011;3:189-96.

2. Sadique J, Chandra T, Thenmozhi V, Elango V. The anti-inflammatory activity of Enicostemma littorale and Mullogo cerviana. Biochem Med Metab Biol 1987;37:167-76

3. Paul RK, Jabbar A, Rashid MA. Antiulcer activity of Mikania cordata. Fitoterapia 2000;71:701-3.

4. Ahmed M, Rahman MT, Alimuzzaman M, Shilpi JA. Analgesic sesquiterpene dilactone from Mikania cordata. Fitoterapia 2001;72:979 21

5. Bhattacharya S, Nag AK. Chemical constituents of the essential oil of Mikania cordata (Burm) B.L. Robinson root extract in rodent. J Essent Oil Res 1992;6:255-9. 
6. Bishayee A, Chatterjee M. Anticarciogenic biological response of Mikania cordata: Reflections in hepatic biotransformation systems. Cancer Lett 1994;81:193-200.

7. Chowdhury NS, Alam MB, Zahan R, Sultana S, Nahar K, Haque ME. Antimicrobial and toxicity studies of different fractions of the aerial parts of the Mikania cordata. Int J Pharm Life Sci 2011;2:592-8.

8. Heyne K. Usefull Indonesia Plant. Jakarta: Yayasan Sarana Wana Jaya; 1987. p. 551-2.

9. Wiart C. Ethnopharmacology of Medicinal Plants: Asia and the Pacific. Totowa: Humana Press Inc.; 2006. p. 36.

10. Ditjen PO. Farmakope Indonesia. Vol. 4. Jakarta: Depkes RI; 1995. p. 896-8.

11. Basset J, Denney RC, Jeffrey GH, Mendham J. Buku Ajar Vogel: Kimia Analisis Kuantitatif Anorganik. ${ }^{\text {th }}$ ed. Jakarta: EGC; 2018.

12. Sinaga SM, Iksen I, Haro G, Wardany S. Potency of chives (Allium schoenoprasum L.) leaves infuse as inhibitor calcium lithogenesis on urinary tract. Asian J Pharm Clin Res 2018;11:77-80.

13. Indonesia's Department of Health. Materia Medika. Vol. 6. Jakarta: National Agency of Drug and Food Control; 1995. p. 297-307.

14. Farnsworth NR. Biologycal and phytochemical screening of plants. J Pharm Sci 1996;55:225-76.

15. Harbone JB. Phtyochemistry method. ITB 1987;2:6, 49

16. Haro G, Sinaga SM, Iksen I, Nerdy N, Theerachetmongkol S. Protective effects of chives leaves (Allium schoenoprasum L.) infusion against ethylene glycol and ammonium chloride induced nephrolithiasis in rats. J Appl Pharm Sci 2017;7:222-5

17. Winter CA, Risley EA, Nuss GW. Carrageenin induced oedema in hindpaws of the rats as an assay of anti-inflammatory drugs. Proc Soc Exp Biol Med 1962;111:544-7.

18. Yu D, Yuan Y, Jiang L, Tai Y, Yang X, Hu F, et al. Anti-inflammatory effects of essential oil in Echinacea purpurea L. Pak J Pharm Sci 2013;26:403-8.

19. Vinueza D, Lopez E, Acosta K, Abdo S. Assessment of antiinflammaotry activity and cytotoxicity of freeze dried hydroalcoholic extract of Bidens andicola on isolated neutrophils. Asian J Pharm Clin Res 2017;10:160-3.

20. Ullah AH, Akter L, Zaman S, Juhara F, Tareq SM, Bhattacharjee R, et al. Anti-inflmammatory and analgesic activities of methanolic seed extract of Sterculia villosa Roxb. Asian J Pharm Clin Res 2015;8:247 51.

21. Laaboudi W, Ghanam J, Aissam H, Merzouki M, Benlemlih M. Antiinflammatory and analgesic activities of olive tree extract. Int J Pharm Pharm Sci 2016;8:414-9.

22. Shaikh S, Joshi YM, Kadam V. Comparative study of anti-inflammatory activity if aqueous and methanolic extracts of Hibiscus cannabinus leaf (Malvaceae). Int J Pharm Pharm Sci 2016;8:64-8. 